\title{
宝珠山村の肺がん検診
}

\section{小泉孝子 1}

要旨一一目的.「健康宝珠山村 $21 」$ 計画策定を前に, 資料づくり及び保健事業の見直しを考え, 肺がん検診の問題点 を把握し，今後の事業推進に生かすことを目的としています．研究計画(方法).11)宝珠山村人口動態調査死亡票，2) 宝珠山村疾患別医療受診統計 (毎年 5 月分診療費)，3)宝珠山村肺がん検診受診状況，上記 3 項目の 1994 年から，2001 年までを調査し分析しました。結果・結論. 35\%の高齢社会の宝珠山村では, 脳血管障害等の予防に追われるうちに, 肺がんが高齢者に増加しています. 生活習慣が山村も都市化したことが考えられますが, 70 歳以上の高齢者は, 農林業 の傍ら炭鉱と関わっていたことが原因ではないかと考えます.今後聞き取り調査等で分析が必要と考えます. 受診率を 高くするには, 各種団体と連携をとり効率的な検診の実施と, 住民と十分な協議を重ね, 検診受診の環境づくりが必要 と感じます.（肺癌. 2002;42:832-834)

\begin{abstract}
Objective. Prior to settling on a plan for the "A Healthy Hoshuyama Village for the 21st Century" project, our objective should be to review data collection and health care services, to have a firm grasp of the issues involving lung cancer examinations, and to put a plan based on these observations into action. Research Plan (Procedure ). Information on the following three items were collected from 1994 to 2001 and the results analyzed. 1: Mortality studies that show the dynamic trends in population change in Hoshuyama Village. 2: Excluding illnesses and ailments, medical treatment statistics of Hoshuyama Village (The amount spent every year in five month periods for medical treatment). 3: The current condition of receiving medical examinations for lung cancer in Hoshuyama Village. ResultsConclusion. With regards to $35 \%$ of the elderly population of Hoshuyama Village, at the same time as prevention of cerebrovascular disorders is being actively pursued, lung cancer is increasing among the elderly. It's reasonable to think that the lifestyle of the village has become more urbanized, however, we believe the origin of this increase for persons over the age of 70 may be related to the coal mine located beside the farms and forestry workplaces. And we think that from now on surveying and analyzing hearing examinations will also be necessary. In order to increase the rate of medical examinees, we must obtain the cooperation of the respective groups, administer efficient medical examinations as well as sufficient consultations with the residents, and create a suitable environment for medical examinations. (JJLC. $2002 ; 42: 832-834)$
\end{abstract}

\section{宝珠山村の概要}

福岡県の中東部にあり, 北は添田町, 東は大分県日田 市，西は杷木町・小石原村に接しており，村の面積は $22.56 \mathrm{~km}^{2}$, 総面積の $85 \%$ は山林原野で占められていま す. 1963（昭和 38）年の閉山まで炭鉱で栄えた村です. 2002 年 4 月 1 日の総人口は 1,780 人, 世帯数 558 世帯, 65 歳以上の人口は 623 人, $(35.0 \%)$ と超高齢社会ですが, 空気がおいしく水と緑がきれいな山村です.

医療機関は, 診療所 (開業医) 1 施設, 歯科医院 1 施設, 福祉施設は, 介護老人福祉施設が 1 施設です.

\section{宝珠山村の疾病状況}

\section{イ. 疾患別医療受診統計から}

入院件数は, 脳血管・脳出血疾患 (以下脳血管という) が多く, 消化器系疾患 - 呼吸器系疾患 - 精神 - 全がんと 続きますが，脳血管が 8 件に対して全がんは 3 件と, 2 分の 1 以下の件数です.

入院外でも, 脳血管件数の 3 分の 1 以下が全がんの件 数です.しかし, 2001 年 5 月分の入院費を比較しますと, 全がんの医療費は脳血管の医療費に近づいており, その 差は 300 万円です. 


\section{ロ. 死亡統計から}

1996 年までの死亡の原因は，脳血管が 1 位であった が，1997 年よりがんによる死亡数が急激に増え，2001 年に脳血管と変わりました. 総死亡数の $24.1 \%$ を占めて います．全がんのうち肺がんによる死亡率は，57.0\%で す.

肺がん検診を開始した 1994 年から 2001 年までの肺が んによる死亡数は 11 人です. 1994 年から 2001 年までの 総死亡数の $5.3 \%$, 全がん死亡数の $26.2 \%$ を占めていま す.

男女比は, 男 9 人に対して女 2 人です.

契煙者は, 死亡者 11 人中 6 人 $(54.5 \%)$ と高い数值で す.

11 人の死亡年齢は, 50 代 1 人, 70 代 9 人, 80 代 1 人 です.

\section{宝珠山村の肺がん検診}

\section{イ. 検診の方法}

民間の検診機関に委託して集団検診です. 地区内 3 ケ 所巡回と宝珠山村基幹集落センターで 2 日の 5 日間実施 しています。

各種がん検診・結核検診・基本健康審査の同日検診

で，日曜検診を 1 日実施しています。

年齢は 40 歳以上ですが，希望者は 39 歳以下でも受付 けています。

胸部 X 線検査と喀痰細胞診の併用による肺がん検診
を実施しています。

平成 12 年にエコー検査を導入しました.

\section{口. 周知方法}

個別通知・健康カレンダー・広報誌・有線放送を実施 しています。

\section{八. 要精検者の指導方法}

個別訪問して，本人または家族に面談して，精密検査 の受診を奨励します。未受診者には再度訪問，また検診 機関の保健師さんと連携して指導を実施しています。

\section{二. 検診結果}

1994 年から 2001 年までの総受診者数は 2,547 人, 要精 検者数は 200 人 $(7.85 \%)$ です．福岡県の要精検率は 3.92 $\%$ （2000 年度）です. 1

5 年間の肺がん発見者数は 5 人 $(0.2 \%)$ です. 福岡県 の肺がん発見率は $0.04 \%$ （2000 年度）です。1

発見された人の年齢は, 80 代 2 人（男女), 70 代 3 人 （男）ですが，80 代の 2 人が生存しています.

疑いだった人は 7 人 $(3.5 \%)$ です．年齢は 60 代 3 人， 70 代 4 人です.

がん以外の疾患であった人は 52 人 $(26.0 \%)$ です．宝 珠山村は，1904（明治 37）年から 1963 （昭和 38）年まで 炭鉱で栄えた村だったので，肺疾患や気管支炎等の呼吸 器系疾患が多いです。

把握できなかった人は 6 人 $(3.0 \%)$ です.

異常所見なしの人は 130 人 $(65.0 \%)$ です.

肺がんの受診率は，検診を開始した 1994 年は $49.8 \%$

\begin{tabular}{lcccccccc}
\hline & 1994 & 1995 & 1996 & 1997 & 1998 & 1999 & 2000 & 2001 \\
\hline Cancer & 7 & 2 & 1 & 5 & 8 & 7 & 4 & 7 \\
Lung & 1 & 0 & 0 & 2 & 0 & 2 & 2 & 4 \\
Pneumonia & 6 & 7 & 5 & 4 & 8 & 9 & 8 & 5 \\
CVA & 8 & 1 & 6 & 1 & 1 & 1 & 6 & 6 \\
Heart & 3 & 7 & 2 & 1 & 2 & 5 & 3 & 4 \\
\hline
\end{tabular}

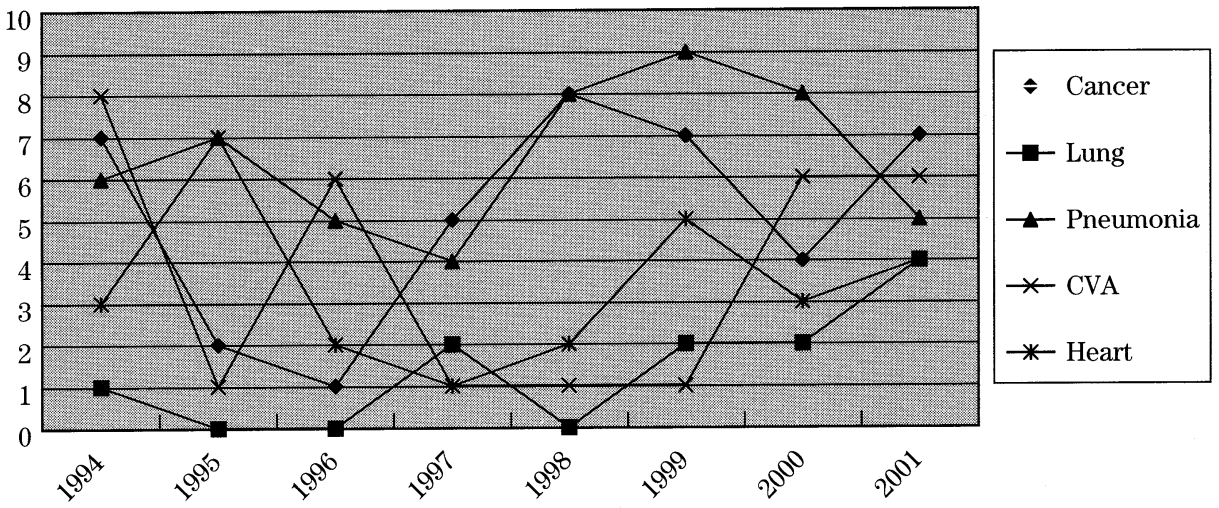

Figure 1. Changes in the Number of Cases Per Major Causes of Death for Hoshuyama Village. 
でしたが，徐々に下がり 2001 年は $41.2 \%$ です．しかし， 精密検查を受診した人は, 1998 年を除いては $100 \%$ で す. 福岡県の肺がん受診率は $13.59 \%$ (2000 年度)です. 1 宝珠山村の受診率の高い年齢は 60 代，低い年歯令は 40 代です。

\section{考 察}

脳血管障害の予防に追われるうちに，じわじわとがん が忍び寄ってきました.とくに肺がんが高齢者に目立っ ています.

喫煙やストレス・食生活等の生活習慣が, 山村も都市 化したことが誘因と考えられますが，村が炭鉱で支えら れていた時代に働き盛りだった 70 歳以上の人たちは, 農 林業の傍ら炭鉱と関わっていたことが原因ではないかと 考えます．聞き取り調查等で分析が必要と考えます.

受診率が下がっていることについては, 企業勤務者の
家族・農業団体者・個人事業主等, 各々の団体でも検診 が実施されています．村の検診を受診した年は把握でき ますが，各々の団体での受診は把握できません．企業や 各種団体と連携をとり, 効率的な検診の実施が必要と考 えます.

住民が自らの意思で検診会場に向かいやすい環境づく りをするには，住民と十分に協議を重ねる必要を感じま す.

おわりに：小さな自治体の，小さな事業報告の機会を与えて くださいました先生方, 関係者の方々に感謝申し上げます.

\section{REFERENCES}

1. 福岡県保健福祉部健康対策課. 福岡県の老人保健 2000 年度. p165. 